\title{
ETIKA DAN FUNGSI MEDIA DALAM TAYANGAN TELEVISI: STUDI PADA PROGRAM ACARA YUK KEEP SMILE DI TRANS TV
}

\author{
Erni Herawati \\ Marketing Communication Department, Faculty of Economics and Communication, BINUS University \\ Jln. K.H. Syahdan No.9, Palmerah, Jakarta Barat 11480 \\ er_ha08@yahoo.com
}

\begin{abstract}
Entertainment as media content in television has been critisized by society. Therefore, this research seeked out how media such as television runs its functions and ethics to society. The objective of this research is to find out the television functions and ethics. This research used qualitative approach and focused on analyzing the functions and ethics of television broadcast. Data were collected by observation and documentations review. The results are entertainment became the prime content of television but the functions have not been implemented responsibly yet to society. The ethics of how television produced and broadcasted the messages, especially the entertainment program, are the main problem. The economic factors become the main concern of the producer compared to the protection for special audiences such as children and teenagers.
\end{abstract}

Keywords: television, media functions, media ethics

\begin{abstract}
ABSTRAK
Program acara hiburan di televisi mendapatkan kritik yang cukup tajam dari masyarakat. Oleh karenanya, penelitian ini mencari jawaban dari permasalahan bagaimana sebenarnya fungsi dan etika media dijalankan oleh stasiun televisi. Tujuan penelitian ini adalah untuk mengetahui bagaimana pelaksanaan fungsi media dan etika media yaitu televisi bagi masyarakat. Penelitian ini menggunakan pendekatan kualitatif dengan unit yang dianalisis adalah fungsi dan etika penyiaran. Data diperoleh dengan cara observasi dan penelusuran terhadap sumber-sumber pustaka. Hasil dari penelitian ini menggambarkan bahwa program-program hiburan pada televisi masih menjadi konten dominan, maka fungsi hiburan pada media televisi lebih menonjol dibandingkan fungsi yang lain. Meskipun demikian, fungsi hiburan tersebut masih belum dijalankan secara bertanggung jawab untuk kepentingan masyarakat. Masalah etika masih menjadi masalah utama dari konten hiburan yang ditampilkan televisi. Pertimbangan ekonomi masih menjadi yang utama dibandingkan perlindungan terhadap khalayak khusus seperti anak-anak dan remaja.
\end{abstract}

Kata kunci: televisi, fungsi media, etika media 


\section{PENDAHULUAN}

Setiap tahun ketika bulan puasa tiba, stasiun-stasiun televisi di Indonesia, khususnya lembaga penyiaran televisi swasta selalu mempunyai rancangan program tayangan yang spesifik. Programprogram yang ditawarkan hampir dipastikan diwarnai dengan suasana yang sesuai dengan momentum bulan puasa, misalnya sinetron, dakwah, musik, komedi situasi, kuis, dll. Program-program antarstasiun televisi saling bersaing untuk bisa mendapatkan jumlah khalayak yang sebanyakbanyaknya. Tidak terkecuali pada bulan puasa tahun 2013, suatu program khusus bulan Ramadhan yang ditayangkan TransTV mencoba memberikan tayangan yang berbeda dengan tayangan-tayangan tahun sebelum, yaitu "YKS" (Yuk Kita Sahur). Acara ini lebih banyak berisi hiburan dibandingkan muatan religius meskipun nama yang dipakai dalam program tayangan tersebut adalah untuk acara sahur. Tingginya rating acara komedi Ramadhan di televisi membuat televisi lain juga menayangkan konten sejenis, misalnya "Sahurnya OVJ", "Sahurnya Pesbukers".

Tingginya rating pada program acara "YKS" tidak berbanding lurus dengan respons masyarakat yang disampaikan ke lembaga Komisi Penyiaran Indonesia (KPI). Terbukti dalam kurun waktu tayangan selama bulan puasa tersebut, program YKS telah mendapatkan kritikan dari masyarakat. Oleh karena itu KPI harus menyampaikan teguran tertulis kepada TransTV karena isi acara YKS dianggap telah melakukan pelanggaran kode etik penyiaran. Di antara acara sejenis pada stasiun televisi yang lain, program YKS terhitung paling banyak melakukan pelanggara norma dalam bentuk pelecehan verbal (Wardhana, 2013).

Teguran KPI yang pertama kepada TransTV disampaikan pada 16 Juli 2013 (KPI, 2013). Secara umum terguran ini menyebutkan bahwa acara "Yuk Kita Sahur" telah menayangkan adegan yang melecehkan orang dan/atau masyarakat dengan kondisi fisik tertentu, pekerjaan tertentu serta orientasi seks dan identitas gender tertentu, dan pelanggaran terhadap norma kesopanan. Teguran kedua KPI disampaikan pada 30 Juli 2013 (KPI, 2013). Teguran kedua ini berisikan alasan yang sama dengan teguran yang pertama.

Menyusul kesuksesan acara YKS (Yuk Kita Sahur) pada bulan Ramadhan, penayangan acara YKS kemudian dilanjutkan TransTV setelah bulan Ramadhan usai. Tampil dengan nama yang berbeda namun brand tetap sama, yaitu YKS yang merupakan kepanjangan "Yuk Keep Smile". Acara ini mulai tayang pertama kali tanggal 31 Agustus 2013, selanjutnya acara tersebut diproduksi dan ditayangkan secara live pada 30 September 2013.

Secara konten acara YKS tidak banyak yang berubah, tetap menampilkan lawakan dan joget sebagai konsep utamanya. YKS mempunyai konten andalan yaitu setiap lagu yang dinyanyikan memiliki format joget masing-masing. Lagu-lagu yang ditampilkan di antaranya "Oplosan”, "Kereta Malam”, “Asik-asik Joss”, dan yang terakhir adalah "Yang Penting Joget”. Program YKS selama tiga bulan terakhir bisa dibilang sebagai juara bertahan peringkat teratas data kepemirsaan Nielsen harian bahkan mingguan (Rayendra, 2014). Acara ini kemudian telah membuat stasiun televisi lain mengikuti untuk membuat acara yang sama atau mengisi dengan konten yang sejenis, seperti "Campur-Campur" dan "Pesbuker" di stasiun televisi ANTV.

Tidak berbeda jauh dari "Yuk Kita Sahur", tayangan acara "Yuk Keep Smile" tidak lama kemudian juga menuai banyak kritik dari masyarakat. Bahkan ada gerakan dari beberapa masyarakat untuk membuat petisi agar acara YKS dihentikan karena dianggap tidak mendidik, tidak berkualitas, penuh dengan kata-kata kasar, dan goyangan tidak jelas (Yanuar, 2014). Senada dengan program YKS versi bulan Ramadhan, program tayangan "Yuk Keep Smile" sudah dua kali medapat teguran dari KPI. Teguran tertulis pertama disampaikan pada 3 Januari 2014, yang menyebutkan bahwa tayangan YKS dianggap menampilkan gerakan tubuh atau tarian yang mengandung unsur erotis pada lagu 
Oplosan, penggunaan pakaian yang minim sehingga mengeksploitasi atau menampilkan bagian-bagian tubuh yang tidak pantas dipertontonkan (KPI, 2014). Program YKS dianggap telah melakukan pelanggaran atas penghormatan terhadap nilai dan norma kesopanan dan kesusilaan, perlindungan anak dan remaja, pelarangan program yang mengeksploitasi bagian tubuh dan menampilkan gerakan erotis, penggolongan program dan ketentuan siaran langsung (KPI, 2014). Teguran kedua disampaikan KPI pada 5 Februari 2014. Program YKS dianggap menayangkan konflik yang mengungkapkan aib dan privasi bintang tamu (KPI, 2014). Jenis pelanggaran dikategorikan sebagai pelanggaran atas penghormatan terhadap norma kesopanan, perlindungan kepada anak, penghormatan terhadap hak privasi, ketentuan tidak menampilkan makian dan kata-kata kasar dan persetujuan narasumber (KPI, 2014).

Berdasarkan uraian, maka dapat dipahami bahwa logika pasar membuat media telah berlombalomba untuk saling mencari keuntungan sebesar-besarnya, termasuk YKS. Sering kali hal ini menciptakan kompetisi yang mengabaikan etika. Oleh karenanya permasalahan yang diangkat dalam penelitian ini yaitu (1) bagaimana pelaksanaan fungsi media televisi khususnya pada program tayangan YKS di TransTV dan (2) bagaimana penerapan etika dalam konten media khususnya pada program tayangan YKS di TransTV.

Penelitian bertujuan antara lain untuk (1) mengetahui fungsi media di masyarakat dalam kaitannya dengan program tayangan di televisi, khususnya YKS di TransTV dan (2) mengetahui etika media dilaksanakan media televisi melalui program tayangan YKS di TransTV. Tulisan ini diharapkan memiliki manfaat akademis dan praktis. Secara akademis, tulisan diharapkan dapat memberikan sumbangan pemikiran pada pengembangan ilmu komunikasi massa berkaitan dengan munculnya permasalahan mengenai etika pada isi pesan di media massa televisi yang akan dapat memperkaya pengembangan pemikiran-pemikiran yang berkaitan dengan konten media. Secara praktis, tulisan diharapkan dapat membawa manfaat pada bagaimana pemikiran pada bidang ilmu komunikasi massa diimplementasikan dalam berbagai peraturan perundang-undangan dan dijadikan sebagai problem solving dalam mengatasi masalah-masalah etika dalam dunia penyiaran, khususnya televisi. Ruang lingkup penelitian ini, yaitu menganalisis program tayangan YKS di TransTV dalam sudut pandang fungsi media bagi masyarakat dan menganalisis program tayangan YKS di TransTV dalam kaitannya dengan penerapan etika media.

\section{Tinjauan Pustaka}

\section{Fungsi Lembaga Penyiaran Televisi di Indonesia}

Televisi sebagai salah satu lembaga komunikasi massa tidak berbeda dengan institusi bisnis lainnya yang bertujuan mencari keuntungan. Salah satu indikator utama bahwa sebuah produksi acara televisi dikatakan sukses adalah melalui jumlah rating yang diperolehnya. Rating yang merupakan salah satu representasi keberadaan jumlah khalayak televisi yang menonton ataupun jumlah khalayak radio yang mendengar yang dapat dijual ke pengiklan. Makin banyak jumlah penonton televisi ataupun pendengar radio pada suatu program acara, maka program tersebut makin mempunyai nilai jual yang tinggi. Pada akhirnya pengiklan hanya akan berinvestasi pada suatu program acara yang sudah pasti ditonton atau didengar oleh khalayak yang besar jumlahnya. Berdasarkan survei, rata-rata orang dewasa Amerika menghabiskan 9 jam 35 menit dalam sehari (60\%) untuk mengonsumsi isi media, dan media yang paling banyak dikonsumsi adalah televisi (Baran, 2012: 22).

Fenomena berkuasanya rating atas suatu produksi siaran dapat dilihat pada kasus ketika acara talk show "Hitam Putih" yang selama ini ditayangkan oleh Trans7 kemudian dihentikan pada 16 Januari 2014. Alasan dihentikannya tayangan adalah share dan rating (Yudono, 2014). Acara ini dianggap tidak bisa bersaing karena share yang tidak memuaskan yaitu hanya senilai 6,5 (Rahmadi, 2014). 
Ketentuan mengenai Lembaga Penyiaran di Indonesia diatur dalam Undang-undang Nomor 32 Tahun 2002. Penyiaran televisi merupakan media komunikasi massa dengar dan pandang, yang menyalurkan gagasan dan informasi dalam bentuk suara dan gambar secara umum baik yang tertutup maupun yang terbuka dan dilaksanakan secara teratur serta berkesinambungan. Dalam undang-undang penyiaran diatur tentang filosofi bagaimana sebenarnya arah pembangunan industri siaran di Indonesia, baik siaran televisi maupun radio. Pengaturan ini didasarkan pada beberapa hal yang utama yaitu; pertama, penyiaran merupakan salah satu perwujudan bahwa negara menjamin hak setiap warga negara untuk bebas berekspresi dan mengeluarkan pendapat melalui media penyiaran. Kedua, industri siaran dalam kegiatannya menggunakan spektrum frekuensi radio yang merupakan milik publik yang harus digunakan untuk sebesar-besar kemakmuran rakyat. Ketiga, sistem penyiaran nasional di Indonesia harus menjamin terciptanya tatanan informasi yang adil dan merata, serta seimbang guna mewujudkan keadilan sosial bagi seluruh rakyat Indonesia. keempat, lembaga penyiaran mempunyai peran yang harus dijalankan dengan kebebasan dan tanggung jawab dalam menjalankan fungsi sebagai media informasi, pendidikan, hiburan kontrol dan perekat sosial. Kelima, siaran yang dipancarkan dan disiarkan secara serentak akan mempunyai dampak yang besar dalam pembentukan pendapat, sikap dan perilaku khalayak, sehingga penyelenggara wajib bertanggung jawab dalam menjaga nilai moral, tata susila, budaya, kepribadian dan kesatuan bangsa yang sesuai dengan sila pertama dan kedua pancasila.

Dalam pandangan fungsionalis media, media merupakan lembaga dalam masyarakat dan memiliki fungsi tertentu bagi masyarakat. Peranan dan fungsi media tersebut dapat dilihat pada efek dari media terhadap masyarakat (McQuail, 2011). McQuail menjelaskan beberapa fungsi media bagi masyarakat yaitu: (1) fungsi informasi, terutama tentang peristiwa dan kondisi yang terjadi dalam masyarakat; (2) fungsi korelasi, media menjelaskan, menafsirkan, memberi komentar atas peristiwa; (3) fungsi keberlanjutan, menampilkan budaya dominan yang berlaku dalam masyarakat beserta perkembangannya; (4) fungsi hiburan, media memberikan kesenangan, pengalihan, dan sebagai sarana relaksasi; (5) fungsi mobilisasi, media dapat mengkampanyekan tujuan-tujuan sosial dan lainnya kepada masyarakat (McQuail, 2011:108).

Fungsi media penyiaran diakomodasi dalam Undang-Undang Penyiaran antara lain sebagai media informasi, pendidikan, hiburan yang sehat, kontrol, dan perekat sosial. Fungsi tambahan lainnya adalah fungsi ekonomi dan kebudayaan. Selain itu perlu dicermati bahwa tujuan penyiaran di Indonesia salah satunya agar terbinanya watak dan jati diri bangsa yang beriman dan bertakwa. Oleh karenanya isi siaran juga diwajibkan untuk sesuai dengan tujuan dan fungsi tersebut. Isi siaran wajib mengandung informasi, pendidikan, hiburan, dan manfaat untuk pembentukan intelektualitas, watak, moral, kemajuan, kekuatan bangsa, menjaga persatuan dan kesatuan, serta mengamalkan nilai-nilai agama dan budaya Indonesia. Hal yang paling penting adalah isi siaran wajib memberikan perlindungan dan pemberdayaan kepada khalayak khusus, yaitu anak-anak dan remaja. Perlindungan ini dijabarkan antara lain bahwa lembaga penyiaran harus menyiarkan mata acara pada waktu yang tepat, wajib mencantumkan dan/atau menyebutkan klasifikasi khalayak sesuai dengan isi siaran.

Hal yang dilarang oleh undang-undang untuk ditampilkan dalam isi siaran antara lain adalah (1) memfitnah, menghasut, menyesatkan dan/atau bohong; (2) menonjolkan unsur kekerasan, cabul, perjudian, penyalahgunaan obat terlarang atau narkotika; (3) mempertentangkan suku, agama, ras, antargolongan; (4) memperolok, merendahkan, melecehkan dan/atau mengabaikan nilai-nilai agama, martabat manusia Indonesia, atau merusak hubungan internasional.

\section{Etika Penyiaran dalam Televisi}

Televsi ditemukan dengan kemampuannya untuk menyiarkan banyak gambar dan suara secara langsung, kemudian ia menjadi jendela dunia karena sifat penyampaiannya yang riil (McQuail, 2011:38). Dalam mempelajari interaksi media, interpretasi bahwa khalayak adalah aktif memang merupakan hal yang penting, tetapi harus disadari bahwa ribuan jam telah dihabiskan masyarakat 
untuk mengonsumsi media dan hal tersebut pasti telah benar-benar memberikan dampak bagi mereka. Pembaca tidak benar-benar kebal terhadap dampak isi media dan teknologi media. Hal ini menimbulkan munculnya banyak pertanyaan, yang di antaranya: bagaimana berkuasanya gambaran dalam media dalam membentuk apa yang dipikirkan dan dirasakan; apakah media memberikan dampak bagaimana masyarakat seharusnya berperilaku; seperti saja pada contoh apakah program kekerasan dalam televisi membuat anak-anak menjadi lebih agresif (Croteau, Hoynes, Milan, 2012:23).

Bourdeau (dalam Haryatmoko, 2007) menjelaskan media elektronik dan komputer memungkinkan pertukaran informasi dalam waktu singkat. Hal ini membuat para investor juga cepat dalam memilih menanamkan modalnya dan mereka akan dengan cepat berubah pikiran kepada pihak mana saja yang dianggap menguntungkan. Investasi jangka pendek menjadi pilihan agar uang segera kembali dengan cepat, dan hal ini harus ditanggapi dengan baik oleh institusi terutama media untuk menyesuaikan diri (Haryatmoko, 2007: 57-58). Dalam hal ini tidak terkecuali televisi di Indonesia, logika pasar tidak hanya dipergunakan untuk mengembalikan modal produksi sebuah program tetapi sekaligus mencari keuntungan. Pada akhirnya pesan-pesan yang tampil di media, khususnya dalam hal ini televisi menjadi sebuah barang dagangan atau komditi yang harus memiliki nilai jual ke khalayak.

Charles (dalam Haryatmoko, 2007) menyatakan bahwa media telah mengubah integrasi sosial, reproduksi budaya dan partisipasi politik:

"Media menyebarkan ke seluruh tubuh sosial tidak hanya ide pembebasan, tetapi juga nilainilai hedonis sehingga akhirnya mempengaruhi integrasi sosial. Integrasi sosial menghadapi kendala dalam bentuk individualime narcisistik. Hanyut dalam arus hedonisme individual, individu semacam ini cenderung memuja kultus masa kini. Hedonisme individualis ini mengabaikan kontrol sosial dari instansi tradisional sehingga norma-norma tradisonal meredup." (Haryatmoko, 2007:25)

Terdapat tiga pertimbangan mengapa etika komunikasi perlu diterapkan secara mendesak. Pertama, karena banyak yang menyadari bahwa media memiliki kekuasaan dan efek yang sangat dasyat kepada khalayak, media mudah memanipulasi dan kemudia mengalienasi masyarakat dari dunia yang sesungguhnya. Kedua, etika komunikasi diharapkan dapat menjaga keseimbangan antara kebebasan berekspresi dan tanggung jawab media terhadap khalayaknya, oleh karenanya media juga harus terbuka terhadap kritik. Ketiga, agar dampak negatif dari media dapat dihindari karena media seringkali mengabaikan nilai dan makna hanya untuk mengikuti logika pasar. Semua pertimbangan ini ditujukan agar publik yang lemah dapat terlindungi (Haryatmoko, 2007:38-39).

Di Amerika Serikat kritik terhadap sejumlah tayangan yang berbau seks, kekerasan, dan bahasa grafis lainnya di televisi sudah dilakukan sejak awal 1950-an. Perhatian ini ditujukan pada ketidaksetujuan terhadap isi dan supaya untuk selanjutnya dibuatkan regulasi terhadap isu tersebut. Pada akhirnya di Amerika Serikat diterbitkan Undang-undang tentang televisi bagi anak-anak. Salah satu hal yang jadi pokok bahasan penting adalah bagaimana membatasi konten media tentang kekerasan atau perilaku seksual karena dikhawatirkan akan merusak pikiran anak muda (Straubhaar \& La Rose, 2004: 220-221).

Uang telah mengubah komunikasi dan menggeser keseimbangan kekuasaan. Uang mempunyai kecenderungan membuat khalayak menjadi produk daripada menjadi konsumen. Hal pokok yang sebenarnya dijual oleh media kepada pengiklan bukanlah kolom dalam surat kabar atau slot waktu tayang pada penyiaran, tetapi justru pembacanya (Baran, 2012:24). Wilson dkk menyebutkan tentang salah satu kategori dampak kekerasan yang ada pada media, yaitu terdapat tiga jenis utama efek menonton kekerasan di televisi : 1) mempelajari sikap dan berperilaku agresif; 2) tidak sensitif terhadap kekerasan; 3) meningkatkan ketakutan akan menjadi korban kekerasan (McQuail, 2011:129). Hasil penelitian di Amerika Serikat yang dilakukan oleh US Surgeon General pada 1960-an dalam 
pandangan Lowery dan De Fleur (1995, dalam McQuail, 2011:238) menghasilkan tiga simpulan, yaitu: (1) konten televisi secara kuat dipenuhi oleh kekerasan; (2) anak-anak semakin banyak yang menghabiskan waktu untuk terpapar konten media yang berisi kekerasan; (3) terdapat bukti dari hipotesis yang mengatakan bahwa menonton hiburan kekerasan akan meningkatkan kecenderungan perilaku agresif. Asosiasi Psikologi Amerika juga menyimpulkan bahwa khalayak heavy viewer pada tonotonan kekerasan yang digambarkan dalam televisi meningkatkan penerimaan terhadap sikap agresif serta menimbulkan perilaku agresif (McQuail, 2011:240). Groebel (1998, dalam McQuail, 2011:240) menjelaskan bahwa sering kali kekerasan dalam media utamanya ditampilkan dalam konteks yang menyenangkan serta memuaskan kebutuhan yang berbeda-beda. Selanjutnya menurut McQuail (2011:241) kekerasan ini akan menciptakan rujukan bagi anak laki-laki untuk dipakai sebagai panutan yang atraktif.

Etika komunikasi seakan tak berdaya menghadapi maraknya kekerasan dalam media, baik pornografi, kekerasan naratif, agresivitas, kekerasan virtual, kekerasan simbolik, dan kekerasan lembut yang manipulatif (Haryatmoko, 2007:119). Program yang berisi kekerasan sangat jarang mempertimbangkan aspek pendidikan, etis, dan efek traumatisme penonton (Haryatmoko, 2007:121). Hal yang tidak diinginkan adalah adanya dampak negatif terhadap khalayak. Lebih dari 300 profesional pertelevisian, 119 penulis, aktor, produser telah menandatangani "pledge of conscience" yang memahami bahwa televisi dan film secara tidak terbantahkan telah memberikan pengaruh yang signifikan pada masyaralat Amerika. Perilaku kekerasan pada televisi dan iklan telah memberikan dampak pada karakter dan perilaku manusia yang tidak dapat diterima dalam masyarakat (Watson, 2004).

\section{METODE}

Penelitian menggunakan pendekatan kualitatif. Di sini peneliti hendak mencari jawaban tentang cara munculnya pengalaman sosial sekaligus bagaimana pengalaman tersebut memiliki makna (Denzin \& Lincoln, 2009). Oleh karena itu, yang utama dari pendekatan kualitatif yaitu penekanan pada pengkajian terhadap proses pembentukan makna yang menekankan pada realitas-realitas yang terbangun secara sosial. Dari hal tersebut peneliti dapat menangkap dan menemukan makna setelah peneliti menyelami data yang diperoleh (Newman, 2013). Peneliti mencoba menyelami dan menggali data mengenai bagaimana program entertainment disajikan melalui media massa televisi dan kemudian program tersebut mengalami dialektika dalam masyarakat. Isi media yang disajikan memunculkan realitas-realitas baru yang membawa pengalaman dan makna baru pula dalam masyarakat.

Data primer diperoleh dengan cara melakukan observasi terhadap pesan-pesan yang disampaikan dalam program acara YKS. Selain itu, penelitian didukung juga dengan data sekunder yang diperoleh dengan penelusuran terhadap sumber-sumber pustaka misalnya: data teguran KPI terhadap acara YKS, peraturan perundang-undangan di bidang penyiaran, peraturan-peraturan KPI, dan literatur lain. Observasi dilakukan agar dapat dilakukan analisis mengenai fenomena melalui keterlibatan peneliti dengan unit yang dianalisis.

Unit yang dianalisis dalam riset ini adalah fungsi media dan etika media penyiaran televisi. Sedangkan objek penelitian adalah isi pesan pada tayangan YKS (Yuk Keep Smile) yang ditayangkan oleh stasiun televisi TransTV. Analisis dilakukan untuk melihat bagaimana konten atau isi pesan yang ada di dalam acara tersebut didistribusikan kepada khalayak dan kemudian ditelaah berdasarkan konsep-konsep mengenai fungsi dan etika media dalam penyiaran. 


\section{HASIL DAN PEMBAHASAN}

Fungsi media penyiaran tidak berbeda dengan fungsi media massa yang lain. Fungsi media televisi yang paling dominan adalah fungsi hiburan. Hal ini disebabkan televisi memiliki karakteristik yang komplit yaitu tidak hanya mengirimkan pesan suara tetapi juga melalui gambar yang bergerak (moving image). Di Indonesia telah disebutkan bahwa fungsi penyiaran antara lain adalah (1) sebagai media informasi, (2) pendidikan, (3) hiburan yang sehat, (4) kontrol dan perekat sosial, dan (5) fungsi ekonomi dan kebudayaan. Dari sini dapat dipahami bahwa fungsi hiburan media bagi masyarakat adalah hal yang bisa diterima, tetapi hiburan yang ditampilkan harus merupakan hiburan yang sehat.

Sesuai dengan filosofi penyiaran bagi Bangsa Indonesia, maka konten penyiaran yang disampaikan oleh media televisi Indonesia juga harus mempertimbangkan bahwa televisi dalam penyiarannya menggunakan spektrum frekuensi radio yang merupakan sumber daya alam terbatas milik publik. Oleh karena itu penggunaannya juga harus dilaksanakan dengan cara yang bertanggung jawab. Selain itu dampak penyiaran mempunyai kadar yang lebih tinggi dibandingkan dengan media massa yang lain karena sifat televisi sebagai teknologi yang dapat mengirimkan pesan yang komplit. Sehingga penyiaran akan dapat memberikan dampak yang besar dalam pembentukan pendapat, sikap dan perilaku khalayak. Dengan demikian maka industri penyiaran wajib bertanggung jawab dalam menjaga nilai moral, tata susila, budaya, kepribadian dan kesatuan bangsa.

Acara YKS jika dipandang dari fungsi media, fungsi yang paling dominan dari acara tersebut adalah fungsi hiburan namun dalam pelaksanaan fungsi tersebut telah dilakukan pengabaian terhadap fungsi yang lain. Fungsi hiburan sendiri harus merupakan hiburan yang sehat. Adegan tarian erotis, kekerasan verbal oleh sesama pemain dan kru YKS, pelecehan terhadap golongan masyarakat lain, penampilan adegan gender tertentu, semuanya mengandung unsur negatif yang tidak sesuai dengan fungsi media yang positif. Pengabaian terhadap fungsi yang mendidik diantaranya dikarenakan stasiun televisi ingin terus mempertahankan dominasi rating yang telah dicapai oleh acara tersebut.

Dari sudut pandang etika media (Haryatmoko, 2007:38-39), bahwa etika media sangat mendesak untuk diterapkan. Terdapat tigal hal yang ditekankan mengenai etika, yaitu: (1) kesadaran bahwa media memiliki kekuasaan dan efek yang dasyat kepada khalayak, media memanipulasi dan mengalienasi masyarakat dari dunia yang sesungguhnya; (2) menjaga keseimbangan antara kebebasan ekspresi dan tanggung jawab media terhadap khalayak; (3) dampak negatif media dapat dihindari.

Menurut Undang-undang Penyiaran, KPI merupakan lembaga negara yang bersifat independen mengatur hal-hal mengenai penyiaran. KPI merupakan wujud peran serta masyarakat berfungsi mewadahi aspirasi serta mewakili kepentingan masyarakat akan penyiaran. Wewenang yang dimiliki oleh KPI adalah pertama, menetapkan Standar Program Siaran (SPS); kedua, menyusun peraturan dan menetapkan Pedoman Perilaku Penyiaran (P3); ketiga, mengawasi pelaksanaan peraturan dan SPS serta P3; keempat, memberikan sanksi terhadap pelanggaran peraturan SPS serta P3; kelima melakukan koordinasi.

Berdasarkan wewenang yang diberikan oleh Undang-Undang Penyiaran, maka KPI menetapkan Peraturan KPI Nomor: 01/P/KPI/03/2012 tentang Pedoman Perilaku Penyiaran (P3). P3 ini merupakan ketentuan-ketentuan bagi lembaga penyiaran yang ditetapkan oleh Komisi Penyiaran Indonesia sebagai panduan tentang batasan perilaku penyelenggaraan penyiaran dan pengawasan penyiaran nasional. SPS adalah standar isi siaran yang berisi tentang batasan-batasan, pelarangan, kewajiban, dan pengaturan penyiaran, serta sanksi berdasarkan Pedoman Perilaku Penyiaran yang ditetapkan oleh KPI. Jika ditelaah, semua hal yang diatur dalam Peraturan KPI tersebut adalah tentang perilaku dan etika media penyiaran baik dalam memproduksi siaran maupun pemberian batasan tentang konten apa saja yang diperbolehkan untuk disiarkan. Dalam kasus yang dibahas di sini 
berkaitan dengan aturan tentang nilai dan norma kesopanan dan kesusilaan, perlindungan kepada anak, perlindungan kepada orang dan kelompok masyarakat tertentu, muatan seksual, dan muatan kekerasan.

Kesadaran bahwa media memiliki efek yang dasyat kepada khalayak sudah tidak diragukan lagi. Kekerasan verbal, penggunaan bahasa yang tidak mendidik, goyangan erotis, pelecehan terhadap golongan masyarakat tertentu, serta penampilan adegan terhadap gender tertentu yang tidak mendidik dipastikan akan membuat efek yang signifikan terhadap khalayak khususnya khalayak yang harus mendapatkan perlindungan yaitu anak-anak dan remaja. Langkah Komisi Penyiaran Indonesia sebagai lembaga idependen yang merupakan lembaga yang bertugas mengawasi perilaku penyiaran untuk melayangkan teguran kepada TransTV merupakan langkah untuk mengingatkan kembali etika media televisi dan perlindungan terhadap khalayak khusus tersebut. Hal ini dikarenakan acara YKS ditayangkan pada jam dimana anak-anak dan remaja masih menonton televisi.

Mengenai kebebasan berekspresi, pada Undang-undang Penyiaran Indonesia telah disebutkan bahwa keberadaan media penyiaran di Indonesia adalah sebagai perwujudan untuk mewadahi aspirasi masyarakat seluruh Indonesia untuk turut serta berekspresi dengan menggunakan saluran publik berupa spektrum frekuensi radio. Setiap warga negara Indonesia tidak terkecuali dapat memanfaatkannya. Kebebasan berekspresi merupakan hak asasi manusia yang dimiliki oleh setiap orang. Namun harus diingat bahwa kebebasan berekspresi harus dilaksanakan dengan bertanggung jawab terutama pada media penyiaran yang telah menggunakan saluran milik publik sehingga konten penyiaran juga harus merefleksikan kepentigan publik dan bukannya kepentingan pemilik media. Demikian juga pada acara YKS, ketika publik mulai resah dengan tayangan yang dianggap tidak mendidik dan tidak mengindahkan norma-norma kesusilaan dan ketertiban umum, maka sudah selayaknya apablia media televisi tidak lagi menjadikan rating sebagai pertimbangan utama, justru kepentingan khalayak yang harus diperhatikan terutama khalayak khusus. Dengan pertimbangan pertama dan kedua tersebut di atas, maka pada akhirnya dampak negatif yang mungkin timbul di kemudian hari akan dapat dihindarkan.

\section{SIMPULAN}

Berdasarkan uraian yang disampaikan, maka dapat disimpulkan hal berikut. Pertama, fungsi media pada media televisi khususnya pada program tayangan YKS lebih banyak hanya bersifat hiburan. Meskipun demikian, fungsi ini belum dilaksanakan secara bertanggung jawab karena belum mempertimbangan kepentingan khalayak terutama khalayak khusus yaitu anak dan remaja. Fungsi ini harus dilaksanakan secara sungguh-sungguh sebab keberadaan media televisi salah satunya adalah penggunaan frekuensi publik, oleh karenanya harus dimanfaatkan untuk sebesar-besar kemakmuran rakyat. Media televisi, khususnya TransTV yang menyiarkan program acara YKS masih mengedepankan konten berdasarkan rating dan bukan pada fungsi media itu sendiri bagi masyarakat. Kedua, etika media dalam program tayangan YKS masih jauh dari etika media yang diinginkan. YKS lebih banyak mengabaikan segi kesusilaan dan kepentingan umum. Kekerasan verbal, penggunaan bahasa yang tidak mendidik, goyangan erotis, pelecehan terhadap golongan masyarakat tertentu, serta penampilan adegan terhadap gender tertentu yang tidak mendidik dipastikan akan membuat efek yang signifikan terhadap khalayak khususnya khalayak yang harus mendapatkan perlindungan, yaitu anakanak dan remaja. 


\section{DAFTAR PUSTAKA}

Baran, S. J. (2012). Pengantar Komunikasi Massa: Melek media dan budaya (ed. 5). Jakarta: Erlangga.

Croteau, D., Hoynes, W., \& Milan, S. (2012). Media/Society: Industries, Images, and Audiences (4th ed). US: Sage.

Denzin, N. K., \& Lincoln, Y. S. (2009). Handbook of Qualitative Research (Terjemahan Dariyanto dkk). Yogyakarta: Pustaka Pelajar.

Haryatmoko. (2007). Etika Komunikasi: Manipulasi Media, Kekerasan, dan Pornografi. Yogyakarta: Kanisius.

KPI. (2012). Pedoman Perilaku Penyiaran (P3) dan Standar Program Siaran (SPS). Diakses dari http://www.kpi.go.id/download/regulasi/P3SPS_2012_Final.pdf

KPI. (2013, 16 Juli). Teguran Tertulis "Yuk Kita Sahur" Trans TV. Dikses dari http://www.kpi.go.id/index.php/lihat-sanksi/31500-teguran-tertulis-yuk-kita-sahur-trans-tv

KPI. (2013, 30 Juli). Teguran Kedua "Yuk Kita Sahur" Trans TV. Diakses dari http://www.kpi.go.id/index.php/lihat-sanksi/31540-teguran-kedua-yuk-kita-sahur-trans-tv.

KPI. (2014, 3 Januari). Teguran untuk YKS (Yuk Keep Smile) Trans TV. Diakses dari http://www.kpi.go.id/index.php/lihat-sanksi/31808-teguran-untuk-yks-yuk-keep-smile-trans-tv

KPI. (2014, 6 Februari). Teguran Tertulis Kedua "Yuk Keep Smile" Trans TV. Diakses dari http://www.kpi.go.id/index.php/lihat-sanksi/31855-teguran-tertulis-kedua-yuk-keep-smiletrans-tv

McQuail, D. (2011). Teori Komunikasi Massa (Buku 1, ed. 6). Jakarta: Salemba Humanika.

Newman, W. L. (2013). Metodologi Penelitian Sosial: Pendekatan Kualitatif dan Kuantitatif (ed. 7). Jakarta: Indeks.

Rahmadi, D. (2014, 16 Januari). Hitam Putih Berhenti Karena Tak Bisa Bersaing dengan YKS. Diakses dari http://www.merdeka.com/peristiwa/hitam-putih-berhenti-karena-tak-bisabersaing-dengan-yks.html

Rayendra, P. (2014, 3 Februari). Ketika Indonesian Idol Lumpuhkan YKS. Diakses dari http://www.tabloidbintang.com/articles/film-tv-musik/ulasan/2998-Ketika-Indonesian-IdolLumpuhkan-YKS.

Republik Indonesia. Undang-Undang Republik Indonesia Nomor 32 Tahun 2002 tentang Penyiaran. Lembaran Negara Republik Indonesia Tahun 2002 Nomor 139, Tambahan Lembaran Negara Republik Indonesia Nomor 4252.

Straubhaar \& La Rose. (2004). Media Now, Understanding media, Culture, and Technology (4 ${ }^{\text {th }}$ ed). USA: Wadsworth/Thomson Learning. 
Wardhana, H. (2013, 19 Juli). 3 Program Sahur di TV Mendapat Sanksi KPI. Diakses dari http://hiburan.kompasiana.com/televisi/2013/07/19/3-program-sahur-di-tv-mendapat-sanksikpi-577894.html

Watson, M. A. (2004). Ethics in entertainment television. Journal of Popular Film \& Television, 31(4), 146-148.

Yanuar, E. R. (2014, 2 Januari). Ribuan Orang Minta YKS Dihentikan. Diakses dari http://celebrity.okezone.com/read/2014/01/02/533/920685/ribuan-orang-minta-yks-trans-tvdihentikan.

Yudono, J. (2014, 16 Januari). Tamatnya Acara “Hitam Putih”. Diakses dari http://entertainment.kompas.com/read/2014/01/16/2128476/Tamatnya.Acara.Hitam.Putih. 